POEF-3039

\title{
PALLET FIRE TEST FOR STEEL DRUM STORAGE ON WOODEN PALLETS
}

June 19, 1992

\author{
By \\ Barry L. Snook \\ Fire Protection Services Department
}

\section{PORTSMOUTH GASEOUS DIFFUSION PLANT P.O. Box 628 Piketon, Ohio 45661}

Managed By

MARTIN MARIETTA ENERGY SYSTEMS, INC.

for the

U.S. Department of Energy

Under Contract DE-AC-05-760R00001 


\title{
DISTRIBUTION
}

\section{MARTIN MARIETTA ENERGY SYSTEMS}

\section{Portsmouth}

N. J. Boesch

J. R. Boyce

MS-5250

M. A. Kane

MS-5250

MS-7550

C. W. Sheward

MS-5009

B. L. Snook

MS-5250

W. D. Strunk

T. D. Taylor

MS-5010

MS-6005

Central Files (2)

Fire Services (15)

Technical Library

Technical Review (2)

MS-1101

MS-5250

MS-2206

MS-2209

\section{Oak Ridue}
R. L. A.tchley
C. K. Bell
B. C. Brown

\author{
A. C. Heitzman \\ K. I. Roy
}

Paducah

R. D. McIntyre

\section{Fernald}

B. L. Steman

\section{MMSC}

G. H. Kitchen

\section{U.S. DEPRARTMENT OF ENERGY}

E. W. Gillespie, ORO-PORT

J. R. Hutton, ORO

D. J. Kuhicki, DOE-HQ

G. W. Yaffe, SR 
(Blank Page) 


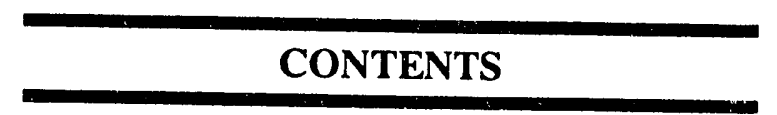

\section{Page}

SUMMARY $\ldots \ldots \ldots \ldots \ldots \ldots \ldots$

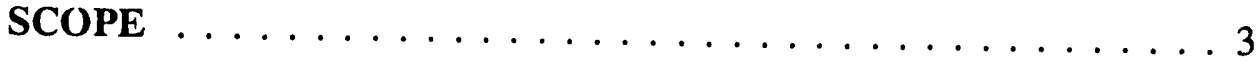

INTRODUCTION $\ldots \ldots \ldots \ldots \ldots \ldots$

PRELIMINARY BURN TEST $\ldots \ldots \ldots \ldots \ldots$

THE FIRE TEST $\ldots \ldots \ldots \ldots \ldots \ldots \ldots$

TEST DATA $\ldots \ldots \ldots \ldots \ldots \ldots \ldots$

TEST ANALYSIS $\ldots \ldots \ldots \ldots \ldots \ldots$

CONCLUSION $\ldots \ldots \ldots \ldots \ldots \ldots$ 


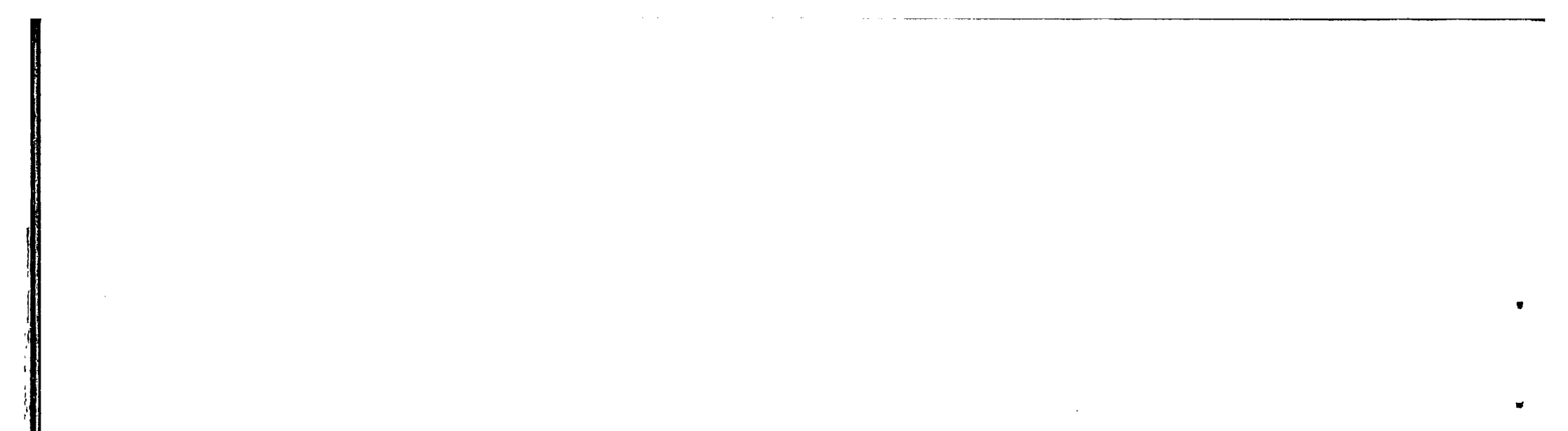

(Blank Page) 


\section{FIGURES}

1. Schematic Drawing of Wood Crib, Shavings, and Alcohol Arrangement ...................... 10

2. Thermocouple Holding Stand for Wood Pallet Fire Test $\ldots \ldots \ldots 11$

3. Nonflammable, Noncombustible Waste Storage Drum Pallet Configuration ...................... 12

4. Wooden Pallet Sectional Cut Out for Wood Crib Ignition Source . . . 13

5. Proposed Noncombustible Waste Drum Storage Configuration for Proposed Fire Test . . . . . . . . . . . . . . . . . . . . . . . . . 14

\section{TABLES}

1. Ignition Solirce Data Table $\ldots \ldots \ldots \ldots \ldots$

2. Fire Test Data Table . . . . . . . . . . . . . . . 18

\section{GRAPHS}

Time Temperature Curve for Ignition Source $\ldots \ldots \ldots$. . . . . . . . . 17

Time Temperature Curve for Fire Test $\ldots \ldots$. . . . . . . . . . . . . . 19

\section{APPENDIX}

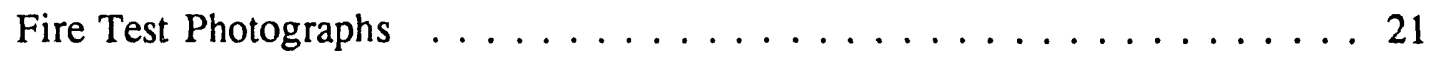


(Blank Page) 


\section{SUMMARY}

A fire test was conducted by the Martin Marietta PORTS Fire Protection Engineering Department on October 3, 1991. This test was designed and setup to simulate a proposed storage configuration. The array consisted of 55-gallon steel drums, filled with noncombustible waste material, placed on wooden pallets stacked three tiers high. Results from the test served as the basis for determining the fire protection requirements for this type of storage.

Data acquired from the test indicated that relatively high temperatures were obtained from the ignition source. These readings, taken during short durations throughout the test, were recorded from digital readouts connected to individual thermocouples. The test demonstrated that the wooden pallets did not significantly ignite and basically selfextinguished once the ignition source was consumed.

Based upon these findings, storage of this type may be placed in the high bay (70 foot ceilings) sprinklered areas. This is providing that good housekeeping is implemented, large ignition sources are not allowed to be stored or parked in the area, and flammable and combustible liquids and solids are not permitted within the storage zones. The area shall also be designated as a "NO SMOKING" area. 


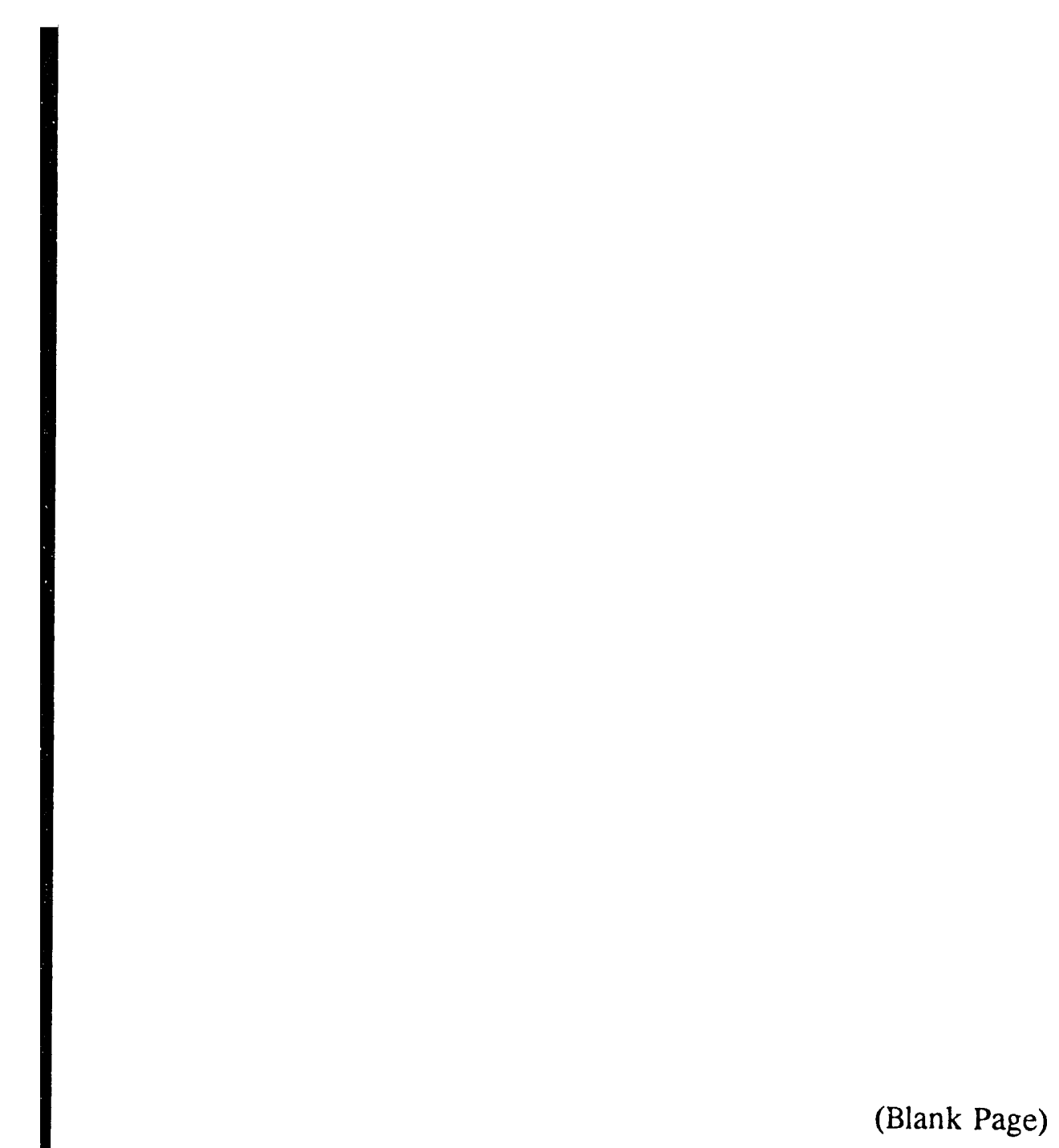

(Blank Page) 


\section{SCOPE}

This test was performed to evaluate the flammability of oak wooden pallets when used to store 55-gallon steel drums of noncombustible materials in a fixed storage array. The validity of this test takes into account practices which are normally implemented in unprotected ordinary combustible storage areas. These procedures include, but are not limited to, good housekeeping, minimizing ignition sources, controlling entry of flammable and combustible liquids and solids within the arrangement, and designating the entire zone as a "NO SMOKING" area.

\section{INTRODUCTION}

The Portsmouth Gaseous Diffusion Plant obtained approval from the Ohio Environmental Protection Agency (OEPA) to store Resource Conservation and Recovery Act (RCRA) hazardous and mixed (hazardous and radioactive) waste in the X-7725 Building. This facility was initially built for the Gas Centrifuge Enrichment Plant. Therefore, fire protection systems were not designed for hazardous waste storage.

Due to the large quantity of hazardous wastes on plant site and the expected quantity of wastes to be generated, Waste Management asked Fire Protection Engineering to consult on ways to safely store hazardous waste in the high bay areas of the X-7725 Building.

The request was to store the containers (55-gallon steel drums) on wood pallets stacked three tiers high. Because wood pallets are classified as "Class A" ordinary combustibles, Fire Protection requested adequate sprinkler protection be in place for this type of storage, or as an alternative, store the containers on noncombustible steel pallets.

Although there is an existing sprinkler system at the ceiling of the high bay area, greater than 70 feet high, it is highly unlikely it would activate in the event of a fire. Likewise, the water spray would be inadequate to control or extinguish the fire because of the elevation. Due to the high open building design, it would be very costly to modify or install an adequate sprinkler system in the high bay area. The second alternative, using noncombustible steel pallets, would also be very costly. The proposed wood pallets for storage cost approximately $\$ 10.00$ per pallet verses $\$ 80.00$ per steel pallet.

Having these unfavorable alternatives in hand, two questions arose:

1. How much fire, using wood pallets, can be anticipated with this type of storage configuration?

2. Will the fire be significant enough to require sprinkler protection?

No certified testing data on this subject was found. Therefore, Fire Protection Engineering proposed a fire test for the purpose of evaluating the combustibility, heat output, and smoke generation of the proposed storage configuration. 


\section{PRELIMINARY BURN TEST}

Prior to the actual fire test, a preliminary burn was performed using a $9^{\prime \prime} \times 9^{\prime \prime} \times 7^{\prime \prime}$ white-pine wood crib. Information acquired from this test provided temperatures which could be expected from the ignition source, as well as the burning duration of the crib.

The preliminary burn test was setup in the X-106B Fire Training Facility. The structure consists of steel columns, pipe trusses, and galvanized steel siding. The south, east, and north sides of the building had openings due to missing sliding doors or cut out sections in the siding. This permitted a small breeze to continuously move through the shelter.

The weather was overcast and cool with a wind of ten (10) to fifteen (15) miles per hour. The temperature was 46 degrees fahrenheit and the relative humidity was approximately seventy (70) percent. The wood crib was placed in the center of the building with no obstructions surrounding it.

Approximately $1 / 2$ pound of wood shavings was placed under the crib. Two ounces of absolute ethyl alcohol was evenly poured over the shavings so as to provide an even burn pattern under the ignition source (See figure 1, page 10). A thermocouple stand, containing three (3) thermocouples, spaced three (3) feet apart, was place above the configuration (See figure 2, page 11). A video camera was set up opposite the stand to document the test.

Upon ignition of the alcohol and shavings, the time clock was started. Readings from the three thermocouples were taken every fifteen (15) seconds up to one minute, and every thirty (30) seconds thereafter. Due to the openings in the structure and the breeze, the thermocolumn of heat from the fire moved from side to side of the thermocouple sensors. This provided inconsistent temperature readings throughout the test. (See Ignition Source Data Table, page 16 and Time Temperature Curve for Ignition So:ırce, page 17). Even with this impediment, recordings of temperatures in excess of 700 degrees fahrenheit were obtained. Temperatures between the wood crib and the concrete floor became excessive enough to cause the concrete to spall and fragment a section approximately $2 "$ x 3 " in diameter. This occurred thirteen (13) minutes into the test. The duration of the test lasted seventeen (17) minutes. Following the preliminary test, temperature data was plotted on a time-temperature curve to illustrate variances of temperature.

\section{THE FIRE TEST}

The Portsmouth Fire Protection Engineering Department, in conjunction with Waste Management, conducted a full-scale fire test on October 3, 1991. The test was conducted with materials which are to be stored in the X-7725 Building. The purpose of the fire test was to help determine if 55-gallon metal drums, filled with noncombustible material, can be stacked three tiers high on wooden pallets without having to install low level sprinkler protection. Combustible loading, flame spread, smoke generation, and heat production were evaluated. 
The materials used for the test included the following:

1. 120 DOT $17 \mathrm{C} 55$-gallon steel drums filled with clean dirt.

2. 30 standard wooden pallets, 48" $\times 48 " \times 5 "$ high. The wood for the pallets was oak and was not treated with fire retardants or other chemicals.

3. White-pine wooden crib ignition source 9" $\times 9 "$ " $\times 7^{\prime \prime}$ high.

4. Approximately $1 / 2$ pound of wood shavings wetted with 2 ounces of absolute ethyl alcohol.

5. Four thermocouples with electronic digital readouts.

6. Timing clock with second hand.

7. Video equipment and still camera.

On the day of the pallet fire test, the weather was partly cloudy with a wind of twelve (12) to fifteen (15) miles per hour. The temperature was $76^{\circ} \mathrm{F}$ and the relative humidity was around fifty-eight (58) percent. These conditions were significantly different as compared to the day of the preliminary ignition source test. Because of these diverse conditions, the wood crib ignition source burned more violently during the pallet fire test. This is by reason of warmer temperatures and lower humidity tending to speed up the rate of pyrolysis, the chemical decomposition of matter through the action of heat.

The test configuration was set up near the center of the X-106B Fire Training Facility. Steel drums and pallets were arranged in duplicate the proposed storage array to be used in the X-7725 Building. There were four (4) drums to a pallet, arranged in three (3) rows. The middle row consisted of four (4) pallets in length, while the outside rows only three (3) pallets long. Aisle widths were three (3) feet between tiers. Each row was stacked three (3) pallets high. The ignition source, consisting of a wooden crib, wood shavings, and absolute ethyl alcohol, was located in the cut out section of the two (2) center pallets (See Figures 1, 3, 4, and 5; pages 10, 12, 13, and 14. The purpose for cutting out a section of the pallets was so the ignition source could be placed on the same surface as the pallets. This enabled the top, bottom, and sides of the pallets to be exposed to the burning pilot.

Four (4) thermocouples were used to measure heat output of the fire at four (4) different heights. Number 1 thermocouple was located at the top of the first layer of drums, number 2 was placed at the top of the second layer of drums, and number 3 was positioned above the third tier of drums. The fourth tinermocouple was installed one foot below ceiling height, approximately 20 feet high, and in line with the outside edge of the center storage pile.

Two video cameras and a still camera were used to document the test. One video camera was placed at the end of the middle row looking through the array of stacked drums. The second mobile camera was located parallel to the rows. The still camera was used to take photographs of the fire as it progressed. Pictures were also taken of the pallets and drums following the test. 
The test was initiated by lighting the wood shavings and alcohol, located under the wood pine crib ignition source. Upon ignition of the wood excelsior, the time clock was started. Readings from all four (4) thermocouples were recorded in intervals of 15 seconds up to one minute, then every minute thereafter. Two Fire Protection Engineers witnessed fire propagation, smoke generation, and flame spread.

Approximately one and one-half minute into the test the wood crib ignition source was fully ignited Flames were extending about three feet above the crib and approximately one to three inches beyond the sides of the source. Thermocouples 1,2 , and 3 began to increase steadily. Thermocouple 4 indicated no temperature change. At the five minute interval, the temperature at thermocouple 1 had escalated above $400^{\circ} \mathrm{F}$. The cut out sections of the bottom pallets ignited, but flame spread in the horizontal direction remained very limited.

As the fire continued to intensify, flame impingement was observed on the bottom of the second tier pallet. At the nine minute interval, thermocouple 1 read $630^{\circ} \mathrm{F}$ while thermocouple 2 (approximately nine feet high) had increased to $262^{\circ} \mathrm{F}$. It was evident that pyrolysis was beginning to take place on the second tier of pallets.

At nine and one-half minutes, thermocouple 1 peaked out at a temperature of $812^{\circ} \mathrm{F}$. Thermocouple 2 had risen to $320^{\circ} \mathrm{F}$ and 3 increased to $141^{\circ} \mathrm{F}$. At the same time, thermocouple 4 indicated a temperature increase of approximately five degrees; rising from 80 to $85^{\circ} \mathrm{F}$. The drums stacked on the pallets, located adjacent to the burning ignition source, were showing signs of burned paint and the collection of smoke soot. There were no observable indications of the drums bulging relative to pressure build up from increased temperatures.

Finally, eleven minutes into the test the temperatures began to gradually fall. The initial heat source (wood crib) was deforming and structurally deteriorating. The bottom pallets, surrounding the ignition source, were still supporting combustion. But flame spread was limited to only a few inches on the burning pallets.

The crib crumbled and fell at fourteen minutes. This caused the burning rate of the crib to decrease to the point of not being able to sustain a flame. Oxygen from the air remained in contact with the char, permitting it to undergo direct glowing combustion. Shortly after this occurrence, approximately 30 seconds, the wood pallets also went into a smoldering state.

At eighteen minutes, readings from all four (4) thermocouples were below $190^{\circ} \mathrm{F}$. Realizing radiant heat losses were too significant to support combustion, the test was terminated at twenty-three (23) minutes.

At the termination of the test, the arrangement was separated pallet by pallet. Pallets exposed directly to the ignition source were photographed and closely examined for charring, heat transfer through drums, over pressurizing of containers, and any unusual or significant findings. 


\section{TEST DATA}

Primary data collected from the fire test was derived by using thermocouples. Actual recordings from the wood crib burn test and the fire test are listed in Tables 1 and 2 , pages 16 and 18. Graphically plotting these range of points on a line graph shows the fire development on a time-temperature curve. The data and graphs are illustrated on pages 17 and 19.

The data and observations from the fire test illustrated two important facts. First, temperatures above $300^{\circ} \mathrm{F}$ were experienced only between the ground level pallet and the bottom of the second tier pallet. Secondly, the oak wocden pallets would not support combustion once the ignition source was consumed. This valuable data, helped determine the combustibility of the wooden pallets.

\section{TEST ANALYSIS}

To be useful, the fire test must provide part of the total body of data needed to predict the performance of the materials under a range of fire conditions which can reasonably be expected in the building. Therefore, it is important that the materials be subjected to an ignition source which may realistically be introduced in day to day operations.

In selecting an appropriate ignition source, a preliminary burn test was performed on a wood crib. Data recorded from the thermocouples indicated temperatures exceeded, for short durations, $700^{\circ} \mathrm{F}$ (See pages 16 and 17). The crib was designed and built to represent an ignition source more severe than what normally would be anticipated. For example, the facility where this type of storage will be implemented is constructed of noncombustible materials. Therefore, quantities of ordinary combustibles such as paper, cloth, wood products, plastics, etc., having a fuel load less than the ignition source, may be introduced.

To illustrate the physical and chemical processes in the fire, it is necessary to discuss the ignition, burning, and eventual extinction of the wood crib and pallet fire.

- Initially, the wood crib was heated by the thermal radiation of the wood shavings. As its surface temperature approaches the boiling point of water, gases/steam slowly evolve from the wood. These initial gases have little, if any, combustible content. As the temperature of the lumber increases above the boiling point of water, the drying process penetrates deeper into the wood interior. This was illustrated during the early moments of the tests.

- With continued heating, the wood surface begins to discolor when the surface temperature approaches $550^{\circ} \mathrm{F}$. This discoloring is visible evidence of pyrolysis. When the wood pyrolyzes, it releases combustible gases while leaving behind a black carbonaceous residue called char. This pyrolysis penetrates deeper into the wood interior as the heating continues. This demonstration was acknowledged as early as one minute into the tests. 
- Soon after active pyrolysis begins, combustible gases evolve rapidly enough to support gas-phase combustion. However, combustion will occur only if there is a piloted ignition sufficient to ignite the gases. Otherwise, the surface temperature must be heated to a much higher temperature before autoignition occurs.

- Once ignition occurs, a diffusion flame rapidly covers the pyrolyzing surface. The diffusion flame shields the pyrolyzing surface from direct contact with oxygen. Meanwhile, the flame heats the fuel surface and causes an increase in the rate of pyrolysis. If the original radiant heat source is withdrawn at ignition, the burning will continue if the wood slab is thin enough. Otherwise, the flames will go out because the wood surface loses too much heat by thermal radiation and thermal conduction into its interior. If there is an adjacent parallel surface (or insulating material) facing the ignitable material, much of the surface radiation loss can be recaptured and returned. Therefore, the ignited wood can continue burning even after the withdrawal of the initial heat source. This explains why the pallets could not burn in the arrangement presented. Once the ignition source was consumed, the pallets were not close enough to recapture the radiant heat losses, therefore self-extinguishing.

- As the burning continues, a char layer builds up. This char layer, which is a good thermal insulator, restricts the flow of heat to the wood interior, and consequently tends to reduce the rate of pyrolysis. The pyrolysis rate also will decrease when the sipply of unpyrolyzed wood runs out. When the pyrolysis rate decreases to the point of not being able to sustain gas-phase combustion, oxygen from the air will come in direct contact with the char, permitting it to undergo direct glowing combustion. This became evident in the test when the wooden crib ignition source collapsed across the pallets. Gas-phase combustion ended, but the wood pieces from the initial source continued to glow bright red.

- Flame spread can be thought of as a continuous succession of piloted ignitions where the flames themselves provide the heat source. It is commonly observed that upward flame spread is much more rapid than downward or horizontal flame spread. This is because hot flames generally travel upward and contribute their heat over a greater area in an upward direction. This was evident during the test by the witnessing of flame impingement on the second tier of pallets, several feet high. Thus each successive "upward ignition" adds a much greater burning area to the fire than a corresponding "downward" or "horizontal" ignition. The test illustrated this feature by exhibiting horizontal burn patterns extending only four to five inches across the pallets.

The ignitability of such a material is controlled by its resistance to heating (thermal inertia), and the temperature rise required for it to begin to pyrolyze. The more dense a material is, the more difficult it is to ignite because of the relatively high thermal inertias present. 
- Burning rates of more hazardous fires are principally governed by the radiant heat transfer from the flame to the pyrolyzing fuel surface. This flame radiation comes primarily from the luminous soot particles in the flames. Combustibles which tend to produce copious amounts of soot or smoke also tend to support more intense fires; despite the fact that their fuel vapors burn less completely, as evidenced by their higher smoke output. As witnessed in the fire test, Fire Protection Engineers indicated there were only very small amounts of soot or smoke generated from the fire. This is another reason why flame propagation was limited.

Putting into perspective these principles of ignition and fire propagation with regard to the results of the fire test, one can assume this type of storage array can be implemented with a relatively fire-safe conscience.

\section{CONCLUSION}

The test illustrated that the wooden pallets did not contribute significantly to fire propagation. The pallets were unable to support gas-phase combustion due to large lo ses of radiant heat. Flame spread was basically in the upward direction but not significant enough to ignite pallets on the second tier. The horizontal flame spread traveled only a few inches across the pallets, therefore limiting the amount of fuel contributed to the fire. Smoke generation was so small that it was determined to be insignificant. The test also illustrated that drum pressures, structural deformation, and pallet instability was so slight that they did not impose a problem.

Based upon these findings, the storage configuration was permitted in the high bay sprinklered areas of the X-7725 Building if the following guidelines can be implemented:

- Good housekeeping must be enforced at all times.

- Large ignition sources, such as forklifts, wood pallet storage, etc., should not be stored or parked idle within the storage area.

- Flammable or combustible liquids and solids shall not be permitted in the storage area in quantities.

- The storage area shall be designated as a "NO SMOKING" area. 


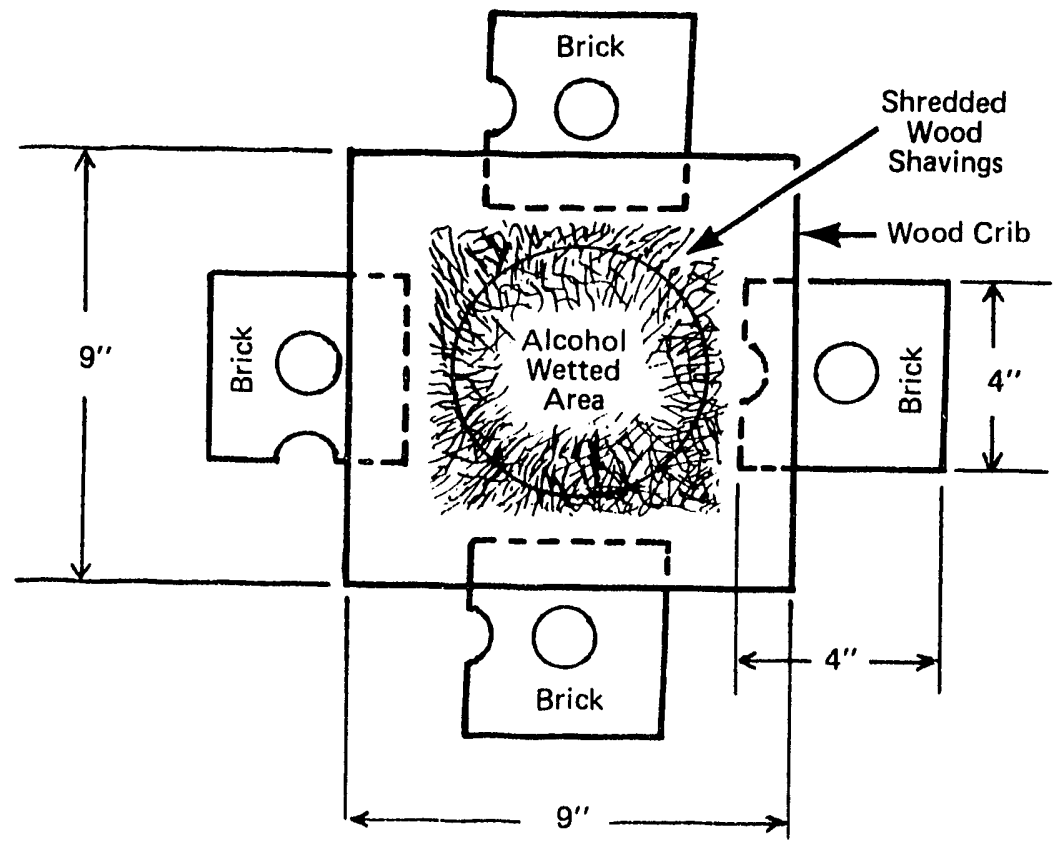

SCHEMATIC DRAWING OF BRICK

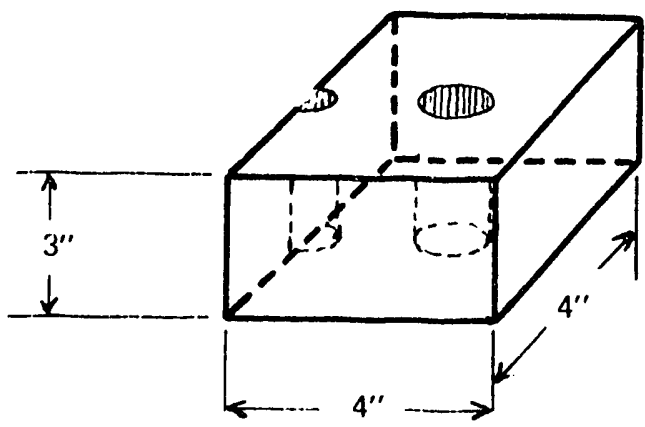

Figure 1

Schematic Drawing of Wood Crib, Shavings, and Alcohol Arrangement 
Base for Thermocouple Stand

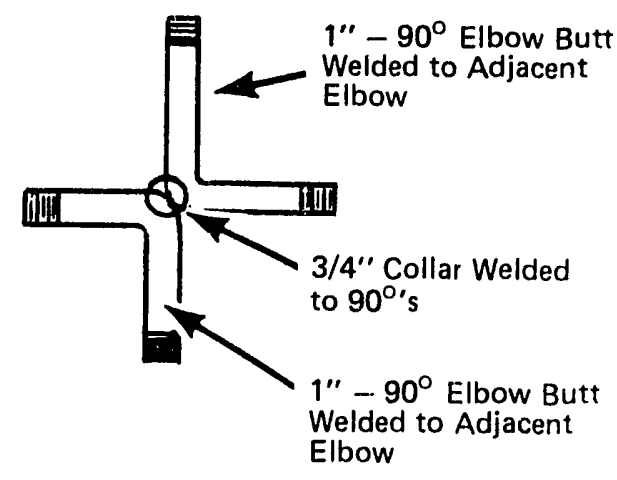

Directions: Butt Weld the two $90^{\circ}$ elbows together. Place the collar on top of welded 90's and weld to each elbow. Make sure 90's are level.

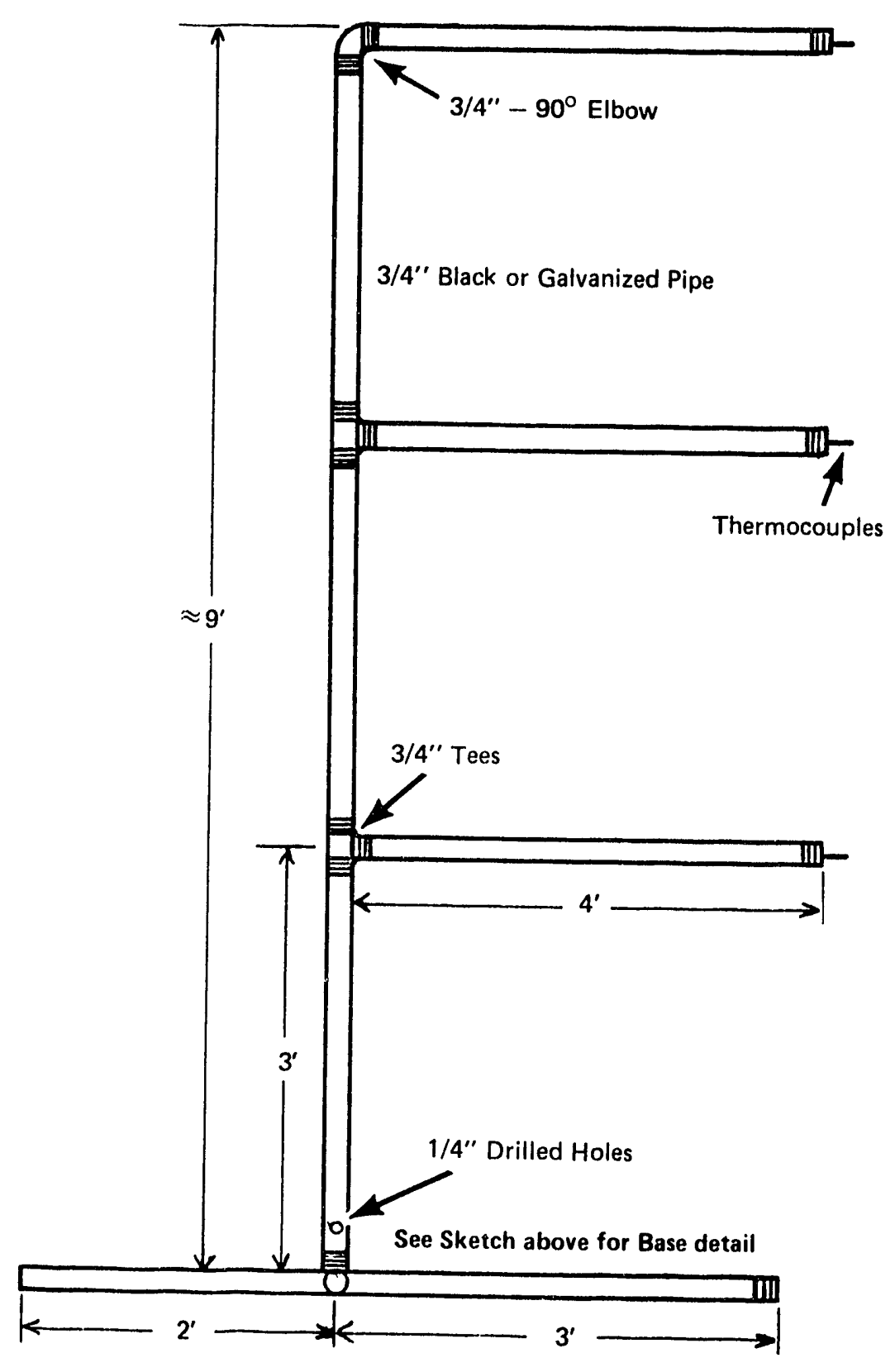

Figure 2

Thermocouple Holding Stand for Wood Pallet Fire Test 

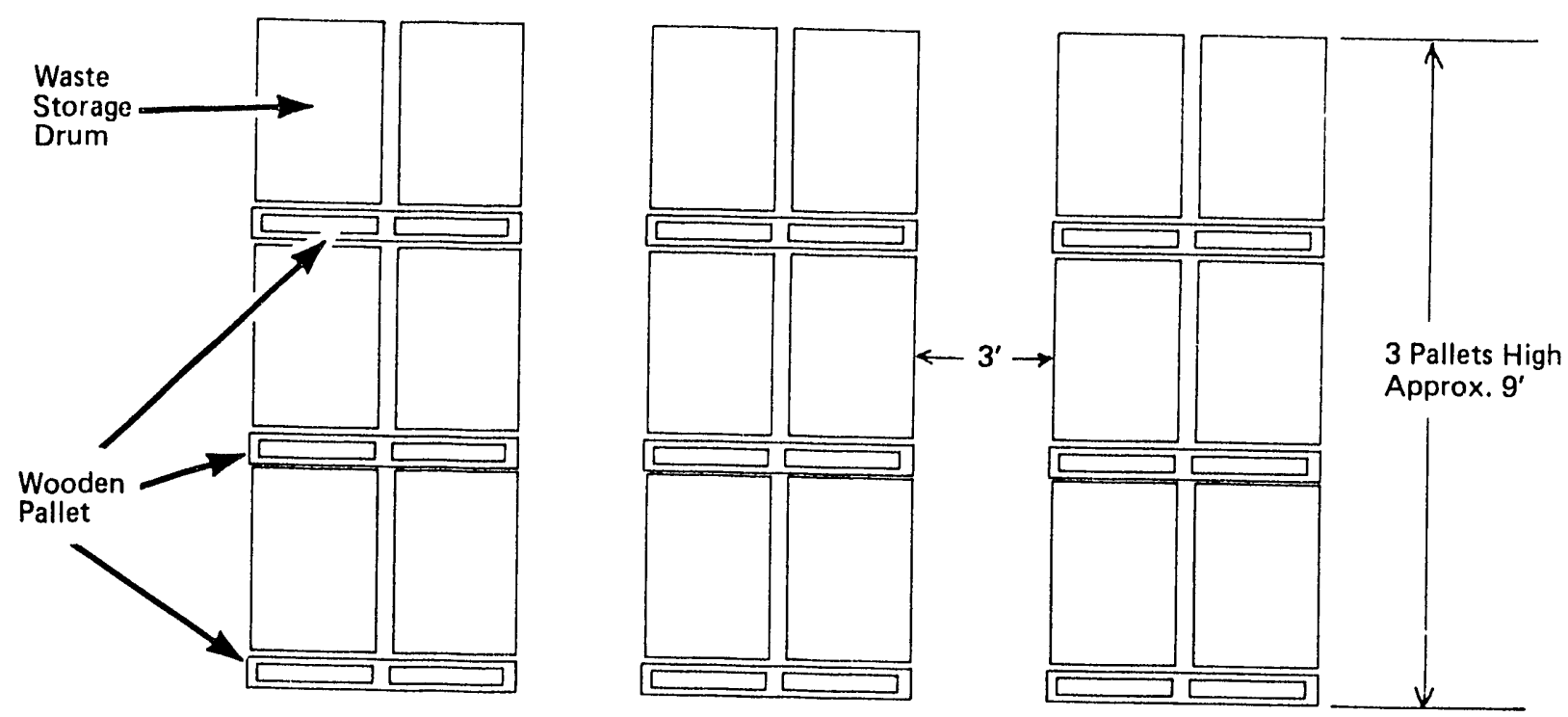

FRONT VIEW

Figure 3

Nonflammable, Noncombustible Waste Storage Drum Pallet Configuration 

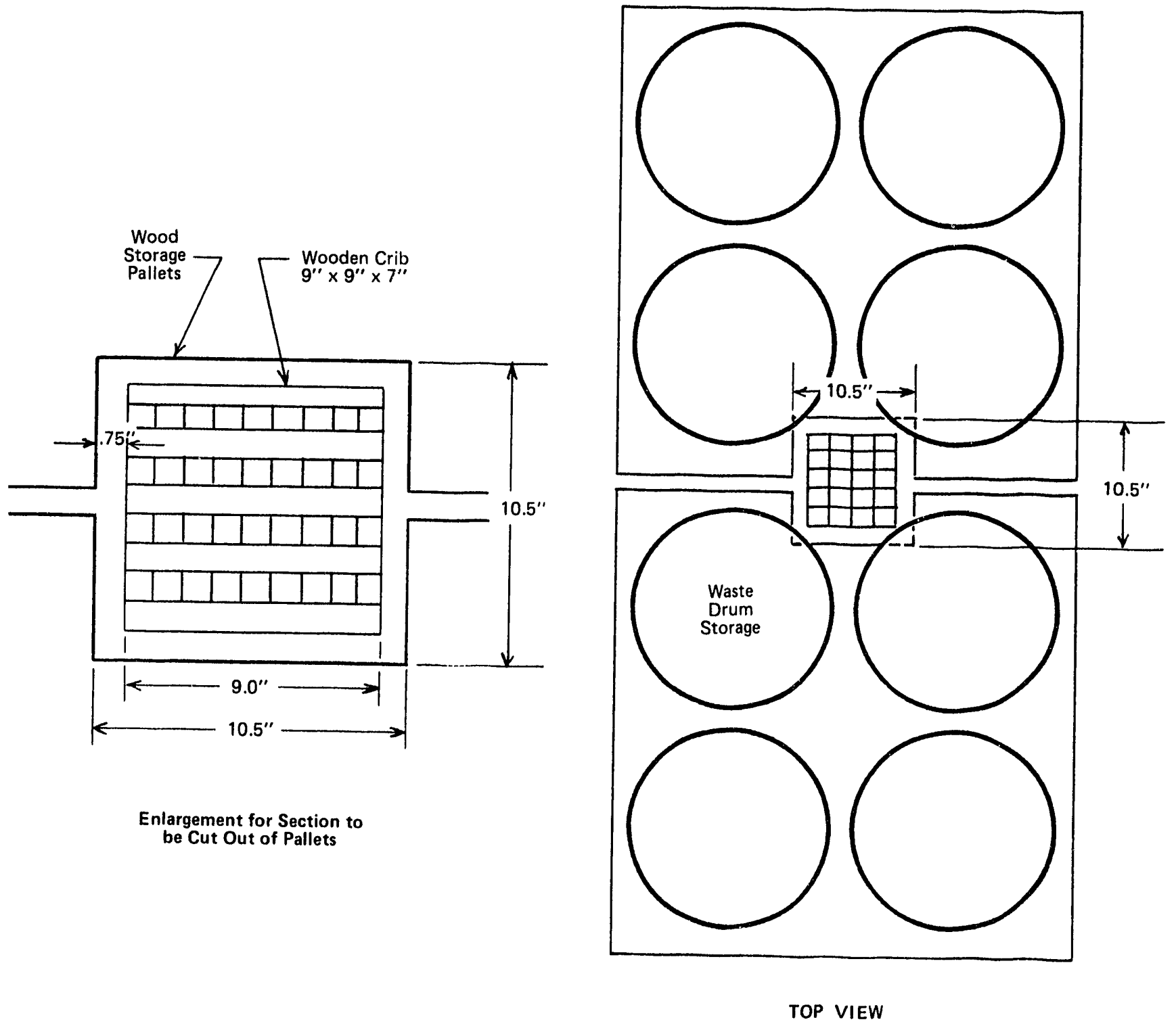

Figure 4

Wooden Pallet Sectional Cut Out for Wood Crib Ignition Source 




TOP VIEW

Figure 5

Proposed Noncombustible Waste Drum Storage

Configuration for Proposed Fire Test 
(Blank Page) 
Table 1

Ignition Source Data Table

\begin{tabular}{|c|c|c|c|}
\hline $\begin{array}{c}\text { Time } \\
\text { (minutes) }\end{array}$ & $\begin{array}{c}\text { Temperature \#1 } \\
\text { (Fahrenheit) }\end{array}$ & $\begin{array}{c}\text { Temperature \#2 } \\
\text { (Fahrenheit) }\end{array}$ & $\begin{array}{c}\text { Temperature \#3 } \\
\text { (Fehrenheit) }\end{array}$ \\
\hline 0 & 46 & 46 & 47 \\
.25 & 73 & 51 & 49 \\
.50 & 90 & 53 & 50 \\
.75 & 169 & 61 & 52 \\
1.0 & 217 & 67 & 55 \\
1.5 & 431 & 106 & 70 \\
2.0 & 430 & 99 & 66 \\
2.5 & 566 & 120 & 70 \\
3.0 & 499 & 111 & 80 \\
3.5 & 279 & 75 & 62 \\
4.0 & 150 & 63 & 56 \\
4.5 & 165 & 61 & 51 \\
5.0 & 107 & 56 & 52 \\
6.0 & 180 & 54 & 54 \\
6.5 & 438 & 74 & 60 \\
7.0 & 706 & 147 & 91 \\
7.5 & 429 & 116 & 80 \\
8.0 & 499 & 132 & 89 \\
8.5 & 445 & 129 & 83 \\
9.0 & 488 & 132 & 84 \\
9.5 & 352 & 115 & 78 \\
10.0 & 208 & 82 & 61 \\
10.5 & 268 & 81 & 60 \\
11.0 & 202 & 68 & 56 \\
11.5 & 127 & 58 & 52 \\
12.0 & 155 & 65 & 51 \\
12.5 & 125 & 57 & 50 \\
13.0 & 87 & 53 & 50 \\
13.5 & 80 & 52 & 50 \\
14.0 & 74 & 52 & 51 \\
14.5 & 70 & 52 & 51 \\
15.0 & 69 & 52 & 50 \\
15.5 & 68 & 52 & 51 \\
16.0 & 65 & 51 & 50 \\
16.5 & & 51 & 5 \\
17.0 & & 51 & 5 \\
\hline
\end{tabular}




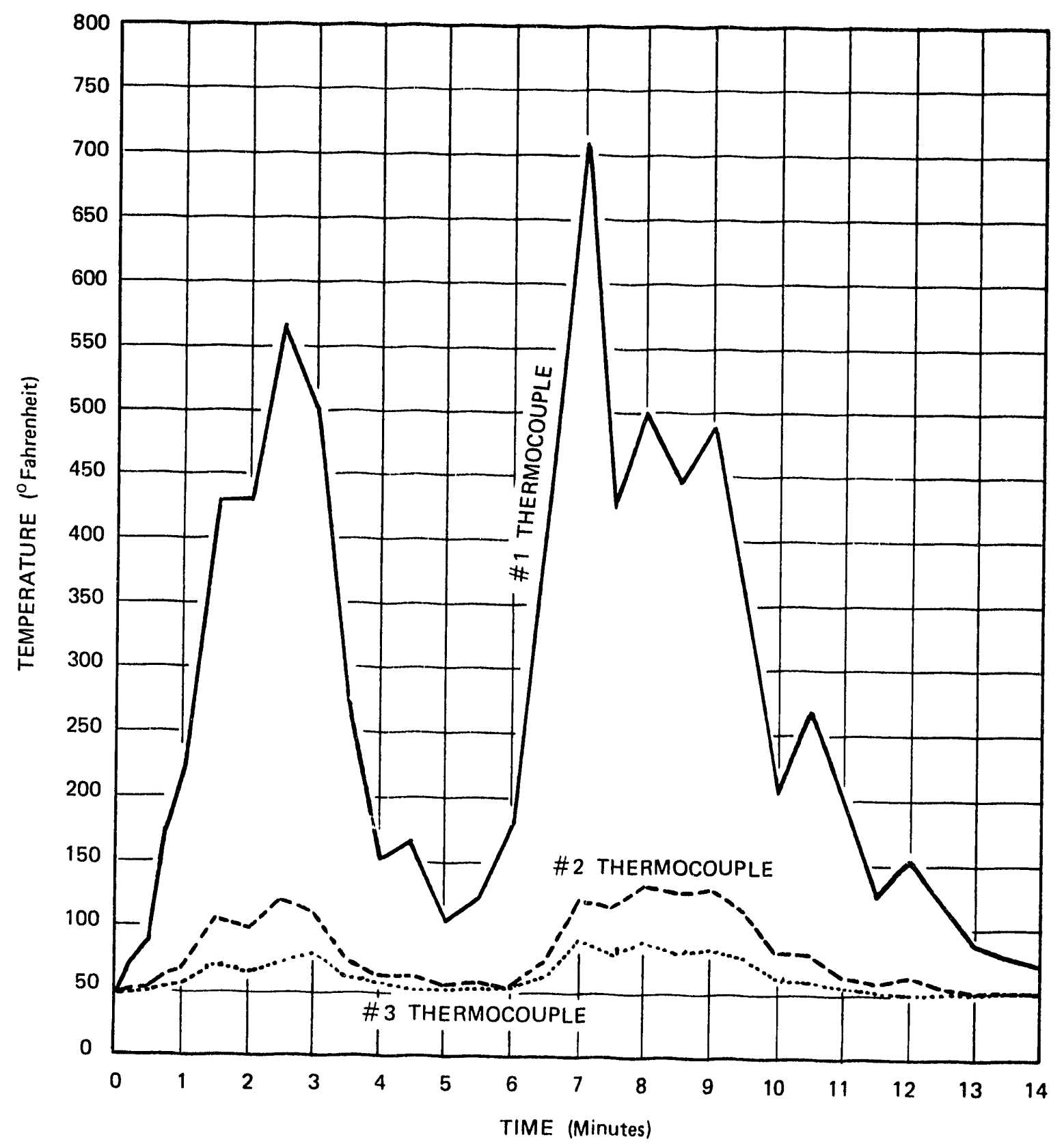

Time Temperature Curve for Ignition Source 
Table 2

Fire Test Data Table

\begin{tabular}{|c|c|c|c|c|}
\hline $\begin{array}{c}\text { Time } \\
\text { (minutes) }\end{array}$ & $\begin{array}{c}\text { Temperature \#1 } \\
\text { (Fahrenheit) }\end{array}$ & $\begin{array}{c}\text { Temperature } \# 2 \\
\text { (Fahrenheit) }\end{array}$ & $\begin{array}{c}\text { Temperature } \# 3 \\
\text { (Fahrenheit) }\end{array}$ & $\begin{array}{c}\text { Temperature \#4 } \\
\text { (Fahrenheit) }\end{array}$ \\
\hline $\begin{array}{c}0 \\
.05 \\
.25 \\
.50 \\
.75 \\
1.0 \\
2.0 \\
3.0 \\
4.0 \\
5.0 \\
6.0 \\
7.0 \\
8.0 \\
8.5 \\
9.0 \\
9.5 \\
10.0 \\
10.5 \\
11.0 \\
11.5 \\
12.0 \\
13.0 \\
14.0 \\
15.0 \\
16.0 \\
17.0 \\
18.0 \\
19.0 \\
20.0 \\
21.0 \\
22.0 \\
23.0\end{array}$ & $\begin{array}{c}78 \\
79 \\
77 \\
79 \\
78 \\
84 \\
95 \\
150 \\
253 \\
445 \\
280 \\
359 \\
342 \\
485 \\
630 \\
810 \\
600 \\
575 \\
550 \\
475 \\
400 \\
357 \\
264 \\
216 \\
191 \\
189 \\
188 \\
165 \\
163 \\
153 \\
135 \\
132\end{array}$ & $\begin{array}{c}78 \\
77 \\
78 \\
77 \\
80 \\
78 \\
78 \\
84 \\
100 \\
162 \\
116 \\
122 \\
108 \\
185 \\
262 \\
320 \\
264 \\
252 \\
240 \\
218 \\
195 \\
188 \\
146 \\
122 \\
119 \\
119 \\
115 \\
112 \\
112 \\
105 \\
102 \\
98\end{array}$ & $\begin{array}{c}78 \\
78 \\
80 \\
80 \\
78 \\
78 \\
78 \\
78 \\
82 \\
105 \\
93 \\
89 \\
84 \\
112 \\
140 \\
140 \\
141 \\
141 \\
141 \\
135 \\
128 \\
123 \\
102 \\
90 \\
93 \\
90 \\
89 \\
88 \\
85 \\
88 \\
86 \\
84\end{array}$ & $\begin{array}{l}79 \\
80 \\
80 \\
80 \\
80 \\
80 \\
80 \\
80 \\
80 \\
81 \\
80 \\
82 \\
82 \\
82 \\
85 \\
85 \\
85 \\
85 \\
84 \\
84 \\
83 \\
81 \\
80 \\
80 \\
79 \\
79 \\
79 \\
79 \\
78 \\
79 \\
79 \\
79\end{array}$ \\
\hline
\end{tabular}




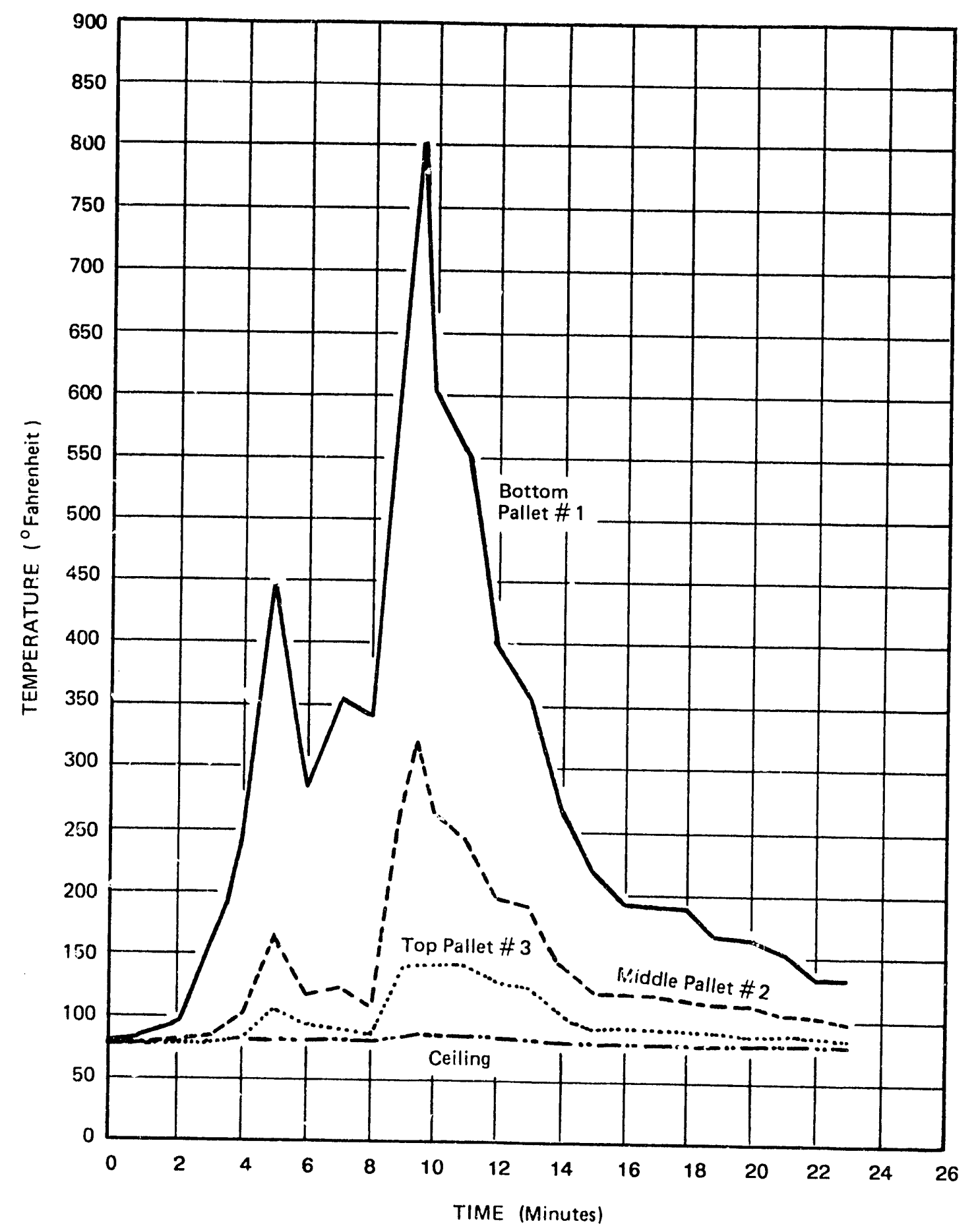

Time Temperature Curve for Fire Test 
(Blank Page) 
APPENDIX 
(Blank Page) 


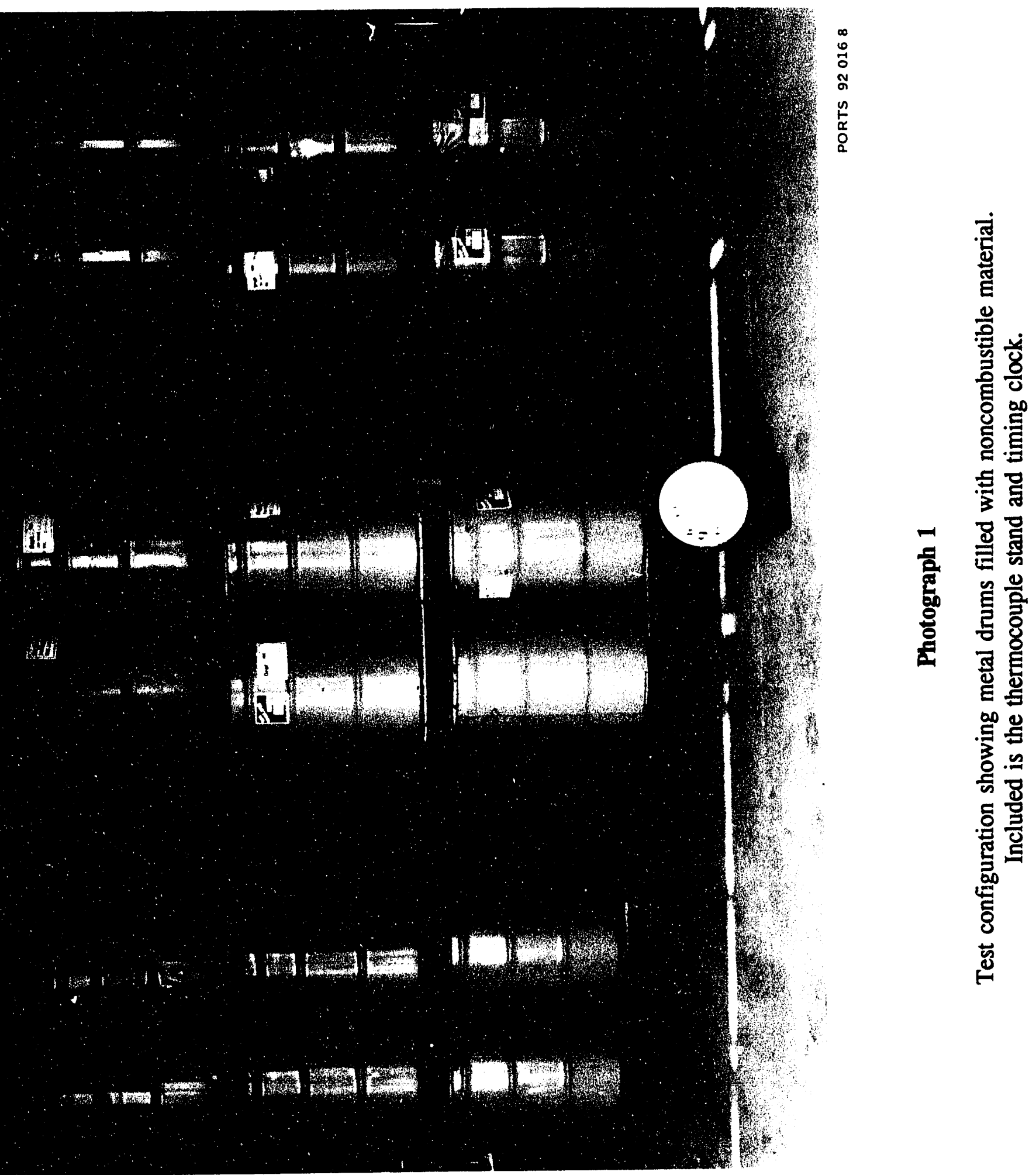


(Blank Page) 


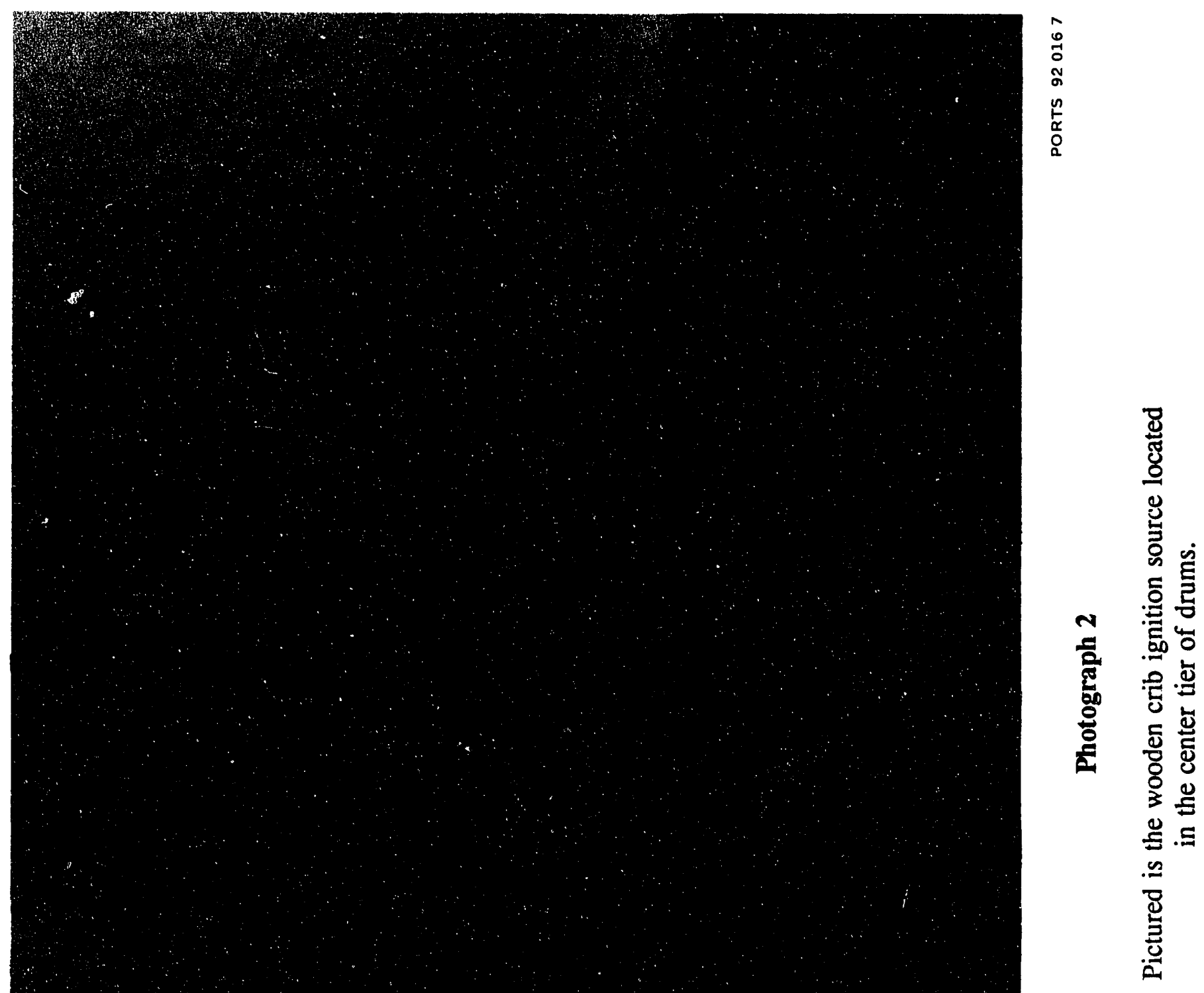





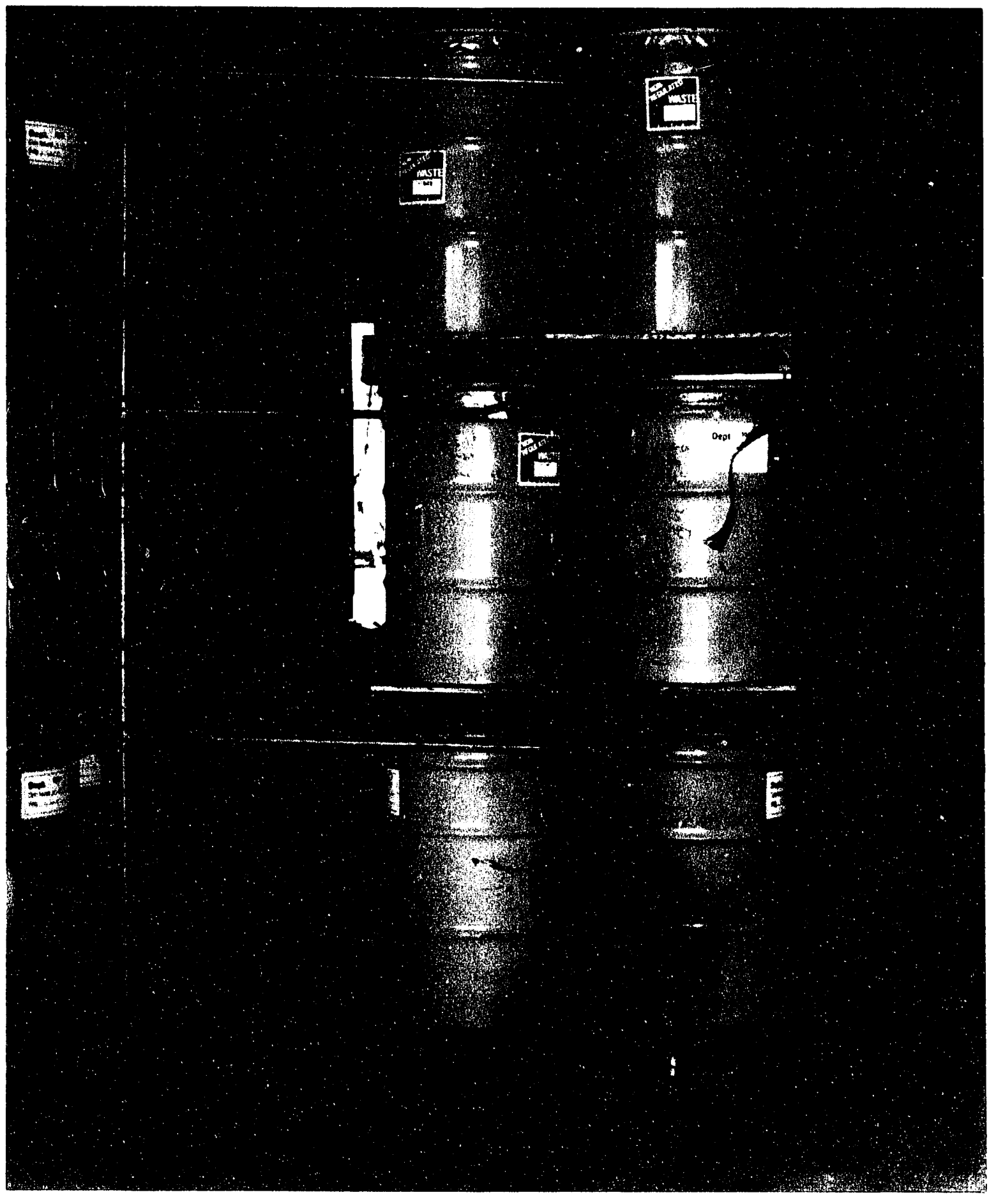

Photograph 3

PORTS 920162

Pictured is the flame spread and the placement of the thermocouple stand in reference to pallet heights. 


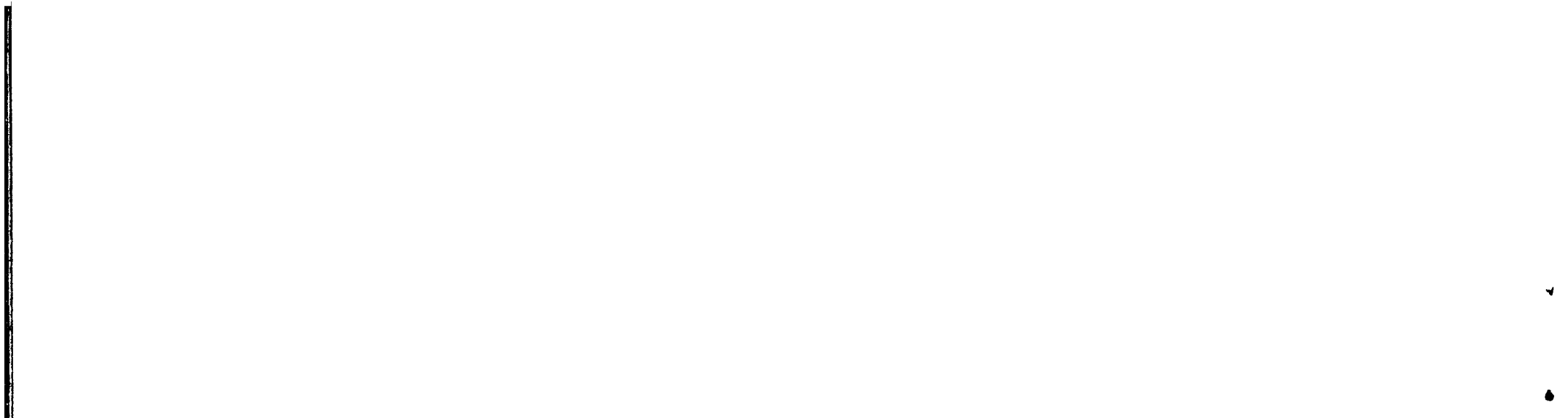

(Blank Page)

. 

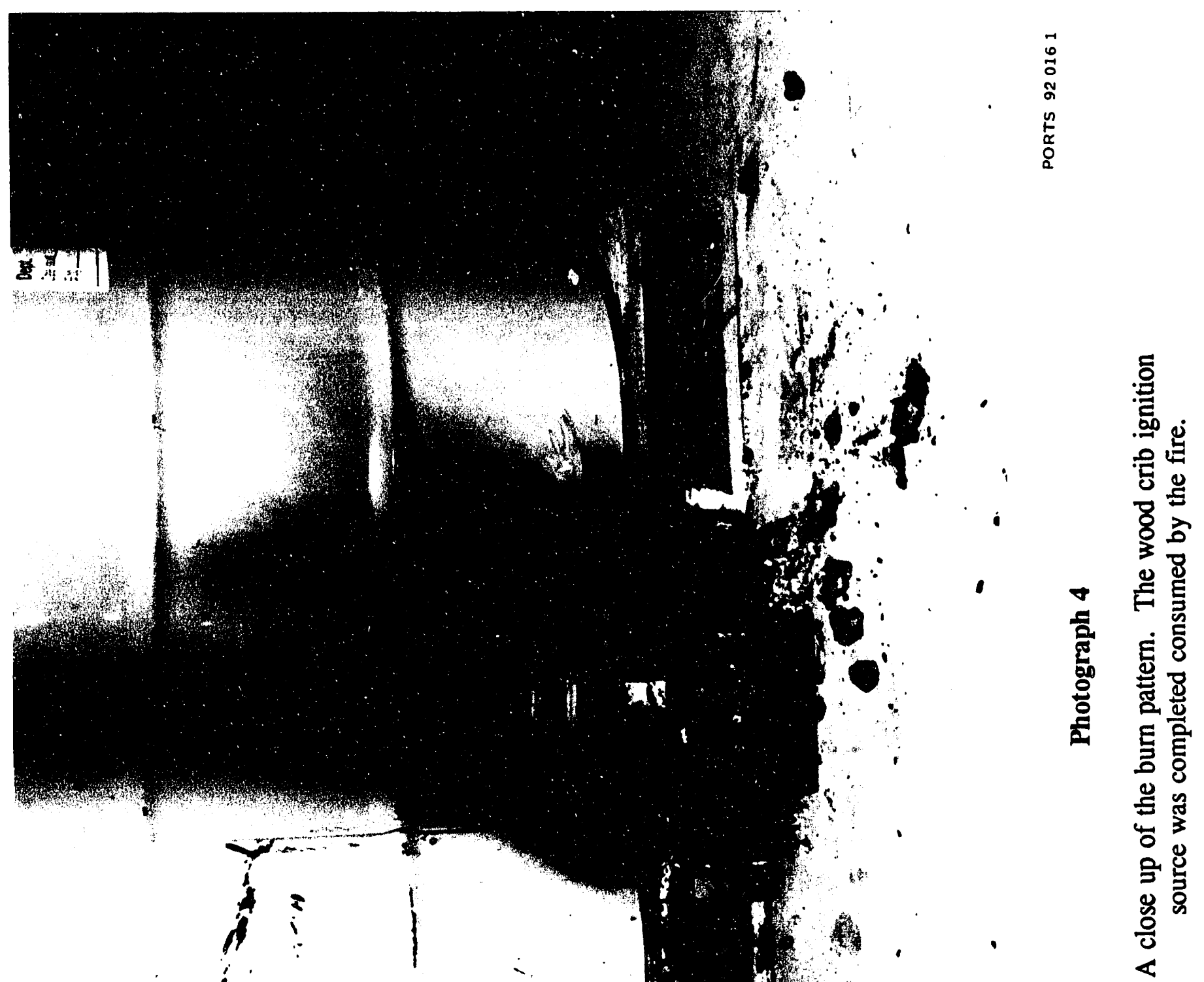

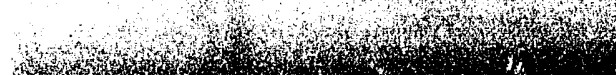

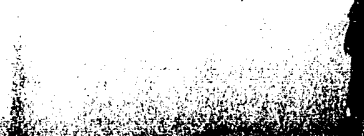
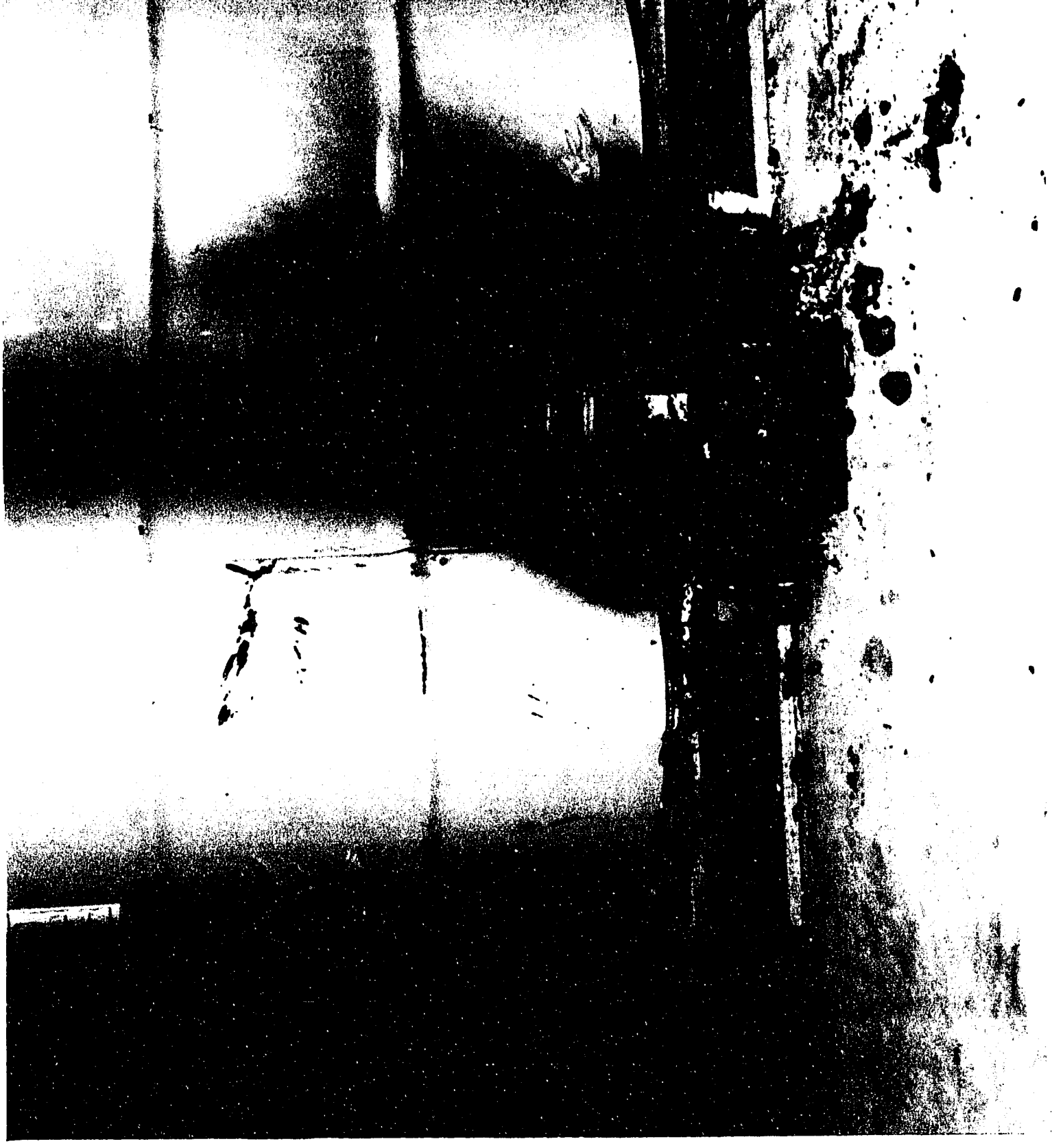


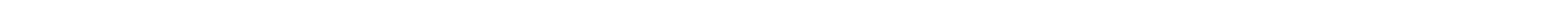


